\title{
Mainstreaming women, equating men: Charting an inclusionary approach to transformative development in the African decade for women
}

\author{
DEJO OLOWU
}

Research Professor (Public Law \& Legal Philosophy), North-West University (Mafikeng Campus)

\section{INTRODUCTION}

In time past, developmental efforts tended to focus on either men or women but seldom on both. ${ }^{1}$ For decades, therefore, development assistance often took the form of providing technologies, loans and training to men. ${ }^{2}$ Starting in the early 1970s, however, analysts pointed out the need to pay more attention to women as agents of development. ${ }^{3}$ The initial focus was to direct more resources to women and, later, focus attention more broadly on gender dynamics and inequalities. ${ }^{4}$ The global movement for gender equality itself has undergone a similar shift over the course of time, from an early emphasis on women alone to the recognition of the need to engage men in the process.

Since the mid-1990s men's role in progress towards gender mainstreaming has been the subject of growing international commitments and activity. In the Beijing Declaration and Platform of Action, adopted by the Fourth World Conference on Women in 1995, governments expressed their resolve to encourage men to participate fully in actions towards gender mainstreaming. This resolve was made in the follow-up meeting, otherwise known as Beijing+5, in 2000. The role of men and boys has also been addressed at other intergovernmental platforms, including the World Summit on Social Development, 1995 and its review session in 2000, as well as the special session of the United Nations (UN) General Assembly on HIV/AIDS in

\footnotetext{
${ }^{1}$ See Jahan R The elusive agenda: Mainstreaming women in development Zed Books (1995) 5-7.

${ }^{2}$ Datta K "A coming of age? Re-conceptualising gender and development in urban Botswana" (2004) 30(2) Journal of Southern African Studies 251.

${ }^{3}$ See De Waal M "Evaluating gender mainstreaming in development projects" (2006) 16(2) Development in Practice 209.

${ }^{4}$ Walby S "Comparative gender mainstreaming in a global era" (2005) 7(4) International Feminist Journal of Politics 453.
} 
2001. All over the world, diverse initiatives which focus on or are inclusive of men have proliferated in fields such as men's violence against women, sexual and reproductive health, HIV/AIDS, labour and trade union rights, as well as fatherhood and families.

In one of the contemporary international expressions of this trend, "The Role of Men and Boys in Achieving Gender Equality" was adopted as one of the themes for the 48th session of the UN Commission on the Status of Women, held in New York, in March 2004. Part of the preparation for this undertaking by the UN Division for the Advancement of Women was an Expert Group Meeting, held in Brazil in October 2003, which attracted experts from across the globe. ${ }^{5}$ The objective of the Expert Group Meeting was to clarify the roles that men and boys could play in achieving gender mainstreaming. Throughout the sessions, the Meeting assessed approaches which have been successful in engaging men and boys in gender mainstreaming, identified obstacles to their participation, and commenced a process of mapping roles for governments, business, civil society, and communities in encouraging men's support. The outcome was the Expert Group Report, 2003, ${ }^{6}$ containing a summary of the debates and recommendations addressed to different actors at different levels. ${ }^{7}$ This Report has virtually become the blueprint for all subsequent discourses and strategies.

As I shall highlight shortly, African states have not been left behind in this global quest for achieving gender equality and mainstreaming for development. From panAfrican platforms to sub-regional and national levels, various initiatives and frameworks have been adopted to advance the cause of equality between men and women and to deepen the protection of women's rights, particularly in the context of development.

While various theories and approaches have been canvassed for mainstreaming women in all policies and agendas for national development, this article queries the perception that views "gender mainstreaming" as an exclusionary instrumentality that will unassailably assert the rights and interests of women. The underpinning assumption of this article is that there is a misunderstanding of the utilitarian essence of the notion of mainstreaming, an assumption that necessitates a reconceptualisation of this notion as merely another tool towards transformative development.

\section{GENDER MAINSTREAMING: ORIGINS, DEFINITIONS AND CONCEPTUAL QUANDARY}

Although the term "mainstreaming" was originally used in the 1970s by experts in the field of education in advocating an educational system that included all kinds of

\footnotetext{
${ }^{5}$ Flood M "Men, gender and development" (2004) 64 Development Bulletin 26.

${ }^{6}$ See Expert Group "The role of men and boys in achieving gender equality: Report of the Expert Group Meeting", organised by DAW in collaboration with ILO and UNAIDS, 21-24 October 2003, Brasilia, Brazil, http://www.un.org/womenwatch/daw/egm/men-boys2003/index.html (accessed 24 January 2011).

${ }^{7}$ Flood (fn 5 above) ibid.
} 
learners in the same classroom rather than separating them according to their learning abilities or disabilities, ${ }^{8}$ the term soon acquired institutionalised fame at the launching of the UN Decade for Women in Mexico in 1975. In that context the concern was how to integrate women into the existing structures of development. ${ }^{9}$ A decade later, at the Third World Conference on Women which took place in Nairobi in 1985, the international community adopted the Forward-Looking Strategies for the Advancement of Women, urging the "effective participation of women in development [and to] be integrated in the formulation and implementation of mainstream programmes and projects". ${ }^{10}$

The notion of integrating gender issues and perspective into the "mainstream" of society was however first comprehensively articulated as a global strategy in the Beijing Platform for Action in 1995. The term "mainstreaming" appeared consistently in 23 places in that document which inter alia implored all organisations and governments to ensure that gender equality is promoted in all areas of social and economic development, including education, health, domestic violence, armed conflict, the economy, decision-making, and human rights. According to the Beijing Conference, "governments and other actors should promote an active and visible policy of mainstreaming a gender perspective in all policies and programmes, so that, before decisions are taken, an analysis is made of the effect on women and men". 11

The UN Economic and Social Council (ECOSOC) elaborated on this concept in 1997 when it defined "gender mainstreaming" as

"the process of assessing the implications for women and men of any planned action, including legislation, policies and programmes, in any area and at all levels. It is a strategy for making women's as well as men's concerns and experiences an integral dimension of the design, implementation, monitoring and evaluation of policies and programmes in all political, economic and societal spheres, so that women and men benefit equally, and inequality is not perpetuated. The ultimate goal of mainstreaming is to achieve gender equality."12

"Gender mainstreaming" has now metamorphosed into an expression often used in development discourses and in the work of civil society and intergovernmental organisations collaborating with governments. Most international organisations and intergovernmental agencies such as the World Bank, the International Monetary Fund, the World Food Programme, the International Labour Organisation and the

${ }^{8}$ See Walby (fn 4 above) ibid; Budig MJ "Gender, self-employment, and earnings: the interlocking structures of family and professional status" (2006) 20 Gender Society 725.

${ }^{9}$ Charlesworth $\mathrm{H}$ "Not waving but drowning: gender mainstreaming and human rights in the United Nations" (2005) 18 Harvard Human Rights Journal 1.

${ }^{10}$ United Nations "The Nairobi Forward-Looking Strategies for the Advancement of Women" in World Conference to Review and Appraise the Achievements of the United Nations Decade for Women New York: United Nations (1985) 114.

${ }^{11}$ Beijing Declaration and Platform for Action Fourth World Conference on Women, 15 September 1995, 87, para 229.

${ }_{12}$ United Nations Economic and Social Council (ECOSOC) Agreed Conclusions 1997/2 18 July 1997, General Assembly Official Records; Fifty-Second Session, Supplement No. 3, available at http://www.unhcr.org/refworld/docid/4652c9fc2.html (accessed 24 January 2011). 
UN Development Programme, as well as major international non-governmental organisations such as Amnesty International, Human Rights Watch, CIVICUS, Oxfam, Transform Africa, and many others, have gender mainstreaming policies.

However, despite the unmistakable commitment of these organisations to the concept of gender mainstreaming, this concept is yet to be fully grasped or properly implemented with verifiable sustainable outcomes anywhere. Often organisations and governments refer to gender mainstreaming without taking the necessary steps to ensure its relevance and sustainability in particular circumstances. In essence, sight is often lost of the reality of gender mainstreaming as a strategic tool towards development, and not an end in itself. Little wonder that apart from cataloguing many of the pronounced difficulties in implementing a "gender" mandate in the development agenda of many multilateral agencies, Charlesworth was quick to assert that "progress is variable and there are signs of gender mainstreaming fatigue within the UN, caused by a lack of adequate training and support". ${ }^{13}$

Other critics have also identified how a lack of clarity, accountability, knowledge and skills among officials on gender issues, or lack of tracking mechanisms for the relative contributions that a particular project might make to different goals, or a combination of the foregoing challenges have endangered implememtation.

The concomitant result of this lopsided approach to gender mainstreaming has been the pursuit of segregated activities for women or targeted interventions to promote women's empowerment, whereas the essence of mainstreaming should be to infuse consideration of women's issues and gender equality into all policy development, research, advocacy, legislation, resource allocation, planning, implementation and monitoring of programmes and projects.

In more recent times there has been a growing consciousness of critiquing the gender mainstreaming concept as the mainstay of all developmental efforts. As shown in the extensive work published by Porter and Sweetman in 2005, the reality is dawning that merely "ensuring that women participate equally with men is not in itself sufficient to guarantee that organisations address gender inequality in their operations, or internally within their own culture, structure, systems, and procedures". ${ }^{14}$ The new thrust engendered by this reality is that the role of men must be factored into gender mainstreaming praxis since men, being such a critical constituency of the social mass can either make or mar the success of gender mainstreaming. ${ }^{15}$

I contend that purposeful gender mainstreaming must involve making sure that goals of gender equality are central to all activities; that is, policy development, research, advocacy, legislation, resource and budgetary allocation, implementation and monitoring of programmes. This is why I align myself with the definitional

\footnotetext{
${ }^{13}$ Charlesworth (fn 9 above) 11.

${ }^{14}$ Porter F \& Sweetman C (eds) Gender mainstreaming: a critical analysis (2005) 6.

${ }^{15}$ See Rao \& Kelleher (fn 14 above) 59. See also Franck AF \& Spehar A women's labour migration in the context of globalisation Brussels: WIDE (2010) 13-15.
} 
approach adopted by the United Kingdom's Department for International Development (DFID) in 2002. According to the DFID, gender mainstreaming is the

“commitment to ensure that women's as well as men's concerns and experiences are integral to the design, implementation, monitoring and evaluation of all legislation, policies and programmes so that women as well as men benefit equally and inequality is not perpetuated. Gender Mainstreaming is integral to all development decisions; it concerns the staffing, procedures and culture of development organisations as well as their programmes; and it is the responsibility of all staff. Gender mainstreaming does not preclude women-only projects. It shifts their focus from women as a target group, to gender equality as a goal. It supports women-only (or men-only) projects designed as strategic interventions to address aspects of gender inequality and promote greater equality." 16

When gender mainstreaming is conceptualised and pursued in this way, even organisations which do not traditionally run gender-specific programming will be able to ensure that their projects reflect gender sensitivity. The overarching objective here is "transformative development" in which all facets of society integrate gender concerns for purposes of growth and progress.

\section{GENDER MAINSTREAMING: THE AFRICAN CONTEXT}

There is no shortage of scholarly works or popular literature when the subject revolves around the place and position of women in Africa. Ranging from female genital mutilation to forced marriages, from sexual slavery to domestic violence, from social exclusion to denial of rights and subjugation, and from gender stereotyping to patriarchy, African and non-African scholars and activists frequently showcase African states as the epicentre of all that deny women their worth and dignity. Such expositions are often accompanied by clamouring for the alteration of African culture, customs and practices that have promoted the institutionalisation of these negative phenomena.

The defunct Organisation of African Unity (OAU), as the foremost pan-African inter-governmental body, had held fast to its principle of non-intervention in member states' affairs, a posture that generally weakened the approach of the organisation to human rights generally and women's rights in particular. Its successor, the African Union (AU), has adopted a more interventionist approach to curb human rights violations and, in particular, to assert the rights and dignity of African women. The AU has therefore continued to develop various legal frameworks and to establish relevant institutions towards securing these objectives. Prominent among these pan-African initiatives are the Charter for Social Action, 1999; the Protocol to the African Charter on Human and Peoples' Rights on the Rights of Women in Africa, 2003 (the African Women's Protocol); the Ouagadougou Declaration and Plan of Action on Employment and Poverty Alleviation, 2004; the

${ }^{16}$ Derbyshire, H Gender Manual: A Practical Guide for Development Policy Makers and Practitioners DFID (2002) 9. 
AU Plan of Action on the Family, 2005; the EU-Africa Plan of Action to Combat Trafficking in Human Beings, especially Women and Children, 2007; and the AU Continental Social Policy Framework, 2008. In addition, the AU has also adopted the Solemn Declaration on Gender Equality in Africa, 2004; the Continental Policy Framework and Plan of Action on Sexual and Reproductive Health and Rights, 2005; the Maputo Plan of Action for the Operationalisation of the Continental Policy Framework for Sexual and Reproductive Health and Rights, 2007-2010; and the AU Gender Policy, 2009.

In prioritising its activities towards promoting gender equality in Africa, the $\mathrm{AU}$ Commission has established a Women, Gender and Development Directorate in the Office of its Chairperson to coordinate all activities and programmes relating to gender as well as to ensure that gender is mainstreamed into all AU programmes and policies in accordance with the Decision on Mainstreaming Gender and Women's Issues within the African Union. ${ }^{17}$ It is also significant to note that the AU appointed the Special Rapporteur on Women's Rights in Africa in October 2001 as a thematic human rights mechanism, and in 2009 , at the $12^{\text {th }}$ ordinary session of the AU's apex organ, the Assembly of Heads of State and Government of the AU, declared 2010-2020 the African Decade for Women, calling on Member States, AU organs and regional economic communities to support the implementation of Decade activities. ${ }^{18}$ The decade was formally launched on 15 October 2010, commemorating the year's edition of World Rural Women's Day.

The launch of the African Women's Decade in 2010 coincided with a time when the global women's movement was marking significant landmarks on gender equality and the empowerment of women. The world commemorated thirty years of the Convention on the Elimination of All Forms of Discrimination Again Women (CEDAW), fifteen years of the Beijing Declaration and Platform for Action, ten years of the Millennium Development Goals (MDGs), and five years since the coming into force of the African Women's Protocol. Coming up in such a landmark commemorative year, therefore, the African Decade for Women provides an auspicious impetus and makes it germane to examine what the determinant parameters of the decade's expected outcomes should be.

While there are so many instruments expressing the formal commitments of African governments to the agenda of gender equality and mainstreaming, translating these theoretical promises into concrete action remains a formidable challenge. It is regrettable to note, for instance, that at present only 27 African States are parties to the African Women's Protocol. ${ }^{19}$ Yet this treaty was conceived as the

\footnotetext{
${ }^{17}$ See Gawanas B "The African Union: concepts and implementation mechanisms relating to human rights" in A. Bösl \& J. Diescho (eds.) Human Rights in Africa: Legal Perspectives on their Protection and Promotion Windhoek: Konrad-Adenauer-Stiftung (2009) 132.

${ }^{18}$ African Union (AU) Decision on the African Women's Decade, Assembly/AU/Dec.229 (XII), Addis Ababa, Ethiopia, 1-3 February 2009.

${ }^{19}$ See African Union "List of countries which have signed, ratified/acceded to the Protocol to the African Charter on Human and People's Rights on the Rights of Women in Africa", available at http://www.africa-union.org/root/au/Documents/Treaties/List/Protocol\%20on\%20the\%20Rights\%20of\%20 Women.pdf (accessed 24 January 2011).
} 
linchpin for advancing the cause of women in Africa's transformative development in a sustainable fashion. ${ }^{20}$ Furthermore, at the Africa review of the Beijing Platform for Action (Beijing +15) in November 2009, the outcome was a gloomy depiction of African countries' failure to meet their commitments on gender equality, while progress on the MDGs indicated that Africa is doing poorly on MDG Goal 3 of promoting gender and empowering women. ${ }^{21}$ The multiplicity of continental rhetoric is thus not matched by pace of implementation.

At the national level, various laws and policies have been adopted to end discrimination against women and ensure their mainstreaming in all matters pertaining to development. ${ }^{22}$ African governments have established diverse mechanisms at different levels, including national agencies, to mainstream gender in the formulation of policies, plans and programmes, as well as policy advocacy and monitoring and evaluating the implementation of international, regional and national commitments. Particular attention has been given to the formulation of national gender policies and implementation plans, with some countries having prepared sector-specific gender policies. ${ }^{23}$ Examining the patterns and processes in all 54 African countries will unnecessarily cloud the present discussion.

The Constitution of the Republic of South Africa, 1996, undoubtedly contains the most elaborate normative and institutional framework for the promotion and protection of the rights of women on the African continent. However, the realities of the development agenda in South Africa still leave numerous challenges unaddressed. Indeed, while the South African state has formally embarked on a transformative development agenda built on an emergent constitutional culture and reinforced by vibrant institutions such as the Commission on Gender Equality (CGE), the state, more than a decade after the establishment of constitutional democracy, has yet to evolve an integrative, all-inclusive development agenda. ${ }^{24}$

Broadly speaking, therefore, despite all efforts at establishing gender mainstreaming praxis in Africa, discriminatory practices against women continue while female participation in decision-making remains negligible in many jurisdictions. A little more than a decade ago, the United Nations Development Programme (UNDP) had lamented the overall plight of African women in development:

\footnotetext{
${ }^{20}$ Olowu D "A critique of the rhetoric, ambivalence and promise in the 'Protocol to the African Charter on Human and Peoples' Rights on the Rights of Women in Africa" (2006) 8(1) Human Rights Review 78.

${ }^{21}$ See "The Fifteen-Year review of the implementation of the Beijing Platform for Action", The Point, 29 January 2010, at http://thepoint.gm/africa/gambia/article/the-fifteen-year-review-of-the-implementation-ofthe-beijing-platform-for-action (accessed 24 January 2011).

${ }^{22}$ Gardner T \& McKinney M "The commodification of women's work: theorizing the advancement of African women" (2007) 13 Buffalo Human Rights Law Review 33.

${ }^{23}$ See Baliamoune-Lutz M \& McGillivray M "Gender Inequality and Growth: Evidence from Sub-Saharan Africa and Arab Countries" 1 September 2007, available at http://www.uneca.org/ aec/documents/Mina\%20Baliamoune-Lutz.pdf (accessed 24 January 2011).

${ }^{24}$ Meer S "Freedom for women: mainstreaming gender in the South African liberation struggle and beyond" (2005) 13(2) Gender \& Development 36; Andrews P "Democracy stops at my front door: obstacles to gender equality in South Africa" (2007) 5 Loyola International Law Review 15.
} 
"Women in [Africa] remain disadvantaged in terms of access to and control of economic structures and resources. This is generally due to their subordinate legal status, limited access to productive resources, such as land, technology, credit, education and training, formal employment as well as susceptibility to HIV/AIDS ... married women do not have the same rights as their husbands over family property and decision making." 25

More recent literature is replete with diverse factors to which this state of affairs is attributable: societal discrimination; gender inequalities; women's unequal access to education, health and other social services; harmful traditional practices including forced marriages; the negative involvement of traditional and community leaders; the economic disempowerment of women; legal pluralism; violence and abuse against women and girls; and denial of access to sexual and reproductive health services and rights. ${ }^{26}$ It serves no useful purpose revisiting the volumes of cited works.

Suffice it to say, however, that this is where this article makes its entry point: why is the concept of gender mainstreaming problematic in Africa? What exactly are the connotations of the concept that have rendered it problematic in culture-specific contexts? Should or shouldn't men be integrated into development programming and policy relating to gender? How can male integration be made most beneficial to the goal of transformative development in Africa? What frameworks and benchmarks would inform such an integrative approach? We turn to examine this barrage of questions in some detail, proceeding from the general to the particular.

\section{GENDER MAINSTREAMING: THE EXCLUSIONARY DILEMMA}

Various views have been expressed on the issue of the empowerment of women as social and economic actors. Views have diverged largely because of the lack of a clear consensus on the integration of the global "mantra" of gender mainstreaming into the agenda of women empowerment. If we proceed on the assumption that women's social and economic vulnerabilities constitute a key factor contributing to their marginalisation, it follows that improving their social and economic status should necessarily be fashioned along the position I have canvassed so far in this article because of its positive effects on the other dimensions of development.

\footnotetext{
${ }^{25}$ See United Nations Development Programme (UNDP) SADC Regional Human Development Report UNDP (2000) 81.

${ }^{26}$ See generally Egunyomi D "Access to basic education for girls: the Nigerian experience", in A Oduaran \& HS Bhola (eds) Widening Access to Education as Social Justice Springer (2006) 427; Manji F, Jama MF \& Musa R (eds) Breathing Life into the African Union Protocol on Women's Rights in Africa London: Fahamu Books (2006) 2; Rebouche R “Labour, land, and women's rights in Africa: challenges for the new Protocol on the Rights of Women" (2006) 19(10) Harvard Human Rights Journal 235; Gardner T \& McKinney M "The commodification of women's work: theorizing the advancement of African women" (2007) 13 Buffalo Human Rights Law Review 33; Vojdik VK "Conceptualizing intimate violence and gender equality: a comparative approach" (2008) 31 Fordham International Law Journal 487; Wandia M “Africa: women's rights - looking back or moving forward?” Pambazuka News, 19 November 2009, at http://allafrica.com/stories/200911191103.html (accessed 24 January 2011).
} 
The conviction that it is inevitable to involve men in efforts towards gender equality is rapidly becoming institutionalised in the philosophies and programmes of international organisations. The question of male involvement is now on the agenda in gender and development work, as it is in fields such as sexual and reproductive health, fatherhood and families, work and economy, and interpersonal violence. $^{27}$

Why are men's and boys' roles in progress towards gender equality only now becoming the subject of such consideration? This is the outcome of over three decades of social change. Women's movements and feminism have offered a wideranging critique of the attitudes, practices and cultures among men which sustain gender inequality. Various scholars have argued that there have been disruptions to and contestations of the social organisation of gender in at least three realms. First, in power relations the legitimacy of men's domination has weakened dramatically, in particular under the influence of global feminism. Second, in production relations Western capitalist countries have undergone fundamental changes since World War II; for example, with married women's increased entry into paid employment and the decline of traditionally male areas of primary industry. Finally, there have been important shifts in sexual relations, in particular with the emergence and stabilisation of lesbian and gay sexualities as public alternatives to heterosexuality. Beginning in the 1980s and 1990s in advanced capitalist countries, men's lives have been questioned and debated with passion. ${ }^{28}$

Men show a variety of public responses to such shifts, from active support for feminism to efforts to shore up male privilege. Small groups and networks of men across the globe, often in collaboration with women, are engaged in public efforts in support of gender equality, and men's anti-violence activism is the most visible and well-developed aspect of such efforts. ${ }^{29}$ On the other hand, "men's rights" and "fathers' rights" groups are engaged in an energetic defence of patriarchal masculinity and men's power, particularly in families. ${ }^{30}$

Why then should men be involved in efforts towards gender equality in Africa, and if so, how? The next segment addresses these questions in relation to the field of gender and development, but its themes are relevant for any realm of genderrelated effort. It has been contended that, in developmental matters, there are three broad areas in which men's involvement may be crucial for repositioning women: (a) engaging men as decision-makers and service providers; (b) integrating men into the development process with a "gendered lens"; and (c) targeting groups of

\footnotetext{
${ }^{27}$ See Esplen E Engaging men in gender equality: positive strategies and approaches Institute of Development Studies (2006).

${ }^{28}$ See, for example, Connell RW Masculinities Allen \& Unwin (1995); Segal L "Changing men: masculinities in context" (1993) 22 Theory \& Society 625; Flood 2004 (fn 5 above); Palmary I \& Nunez L "The orthodoxy of gender mainstreaming: Reflecting on gender mainstreaming as a strategy for accomplishing the Millennium Development Goals" (2009) 11(1) Journal of Health Management 65.

${ }^{29}$ Flood (fn 5 above) ibid; Esplen (fn 27 above) 5-8; Mayoux L \& Mackie G Making the strongest links: $a$ practical guide to mainstreaming gender analysis in value chain development ILO (2007).

${ }^{30}$ Flood M Fatherhood and fatherlessness The Australia Institute, Discussion Paper No 59, Sydney (November 2003) 37-42; Baliamoune-Lutz \& McGillivray (fn 24 above) 2.
} 
men and boys when and where they are vulnerable, e.g., in relation to issues of poverty or sexuality. 31

The impulsion for male inclusion is associated with an important shift in how gender issues are conceived and addressed in development work. The paradigm shift from "women in development" (WID) to "gender and development" (GAD) has embodied a greater orientation towards men and arguably provided more room for the addition of men as actors and clients in gender interventionist programmes. ${ }^{32}$ Naturally, men have always been part of the policies and practices of development work, but have often been treated as representing all of humanity, thus perpetuating masculine norms and gender inequalities. The agenda of engaging men is therefore not novel because of whom it addresses, but because of the way it does so. This paradigm shift addresses men as men, that is, as gendered human beings who participate in gender relations.

There has also been a conceptualised emergence of GAD approaches intensifying concentration on men's roles in two ways. First, GAD approaches are characterised in part by the goal of "gender mainstreaming", in which gender issues are made an integral part of organisational thinking and practice. They aim to transform mainstream policy agendas from a gender perspective, rather than merely integrating gender into pre-existing policy concerns, as well as to modify the cultures and operation of developmental institutions. ${ }^{33}$ This has provoked greater interest in addressing the attitudes and practices of men, whether as clients of development agencies or as policy-makers and practitioners. Second, GAD approaches embody a shift towards a more overt focus on gender relations with the aim of creating structural changes in male-female power relations. While they continue to tackle women's experiences and social situations, they also situate these in the context of the social and power relations between men and women.

Before addressing the extent to which the shift from WID to GAD has made a difference to efforts to address men, I shall attempt to chart the justification for this inclusion. At its broadest, the motivation for involving men in gender and development work is based on the recognition that men are both part of the problem and part of the solution. Thus conceptualised, it means gender inequalities will only cease when men join with women in putting an end to the problem. Many of men's attitudes and behaviours will need to change in order for gender equality to be attained. Many men indulge in chauvinistic practices and the preservation of unfair gender relations. Men also often play a crucial role as beneficiaries of the current patriarchal order, as decision-makers and community leaders, with patterns of gender inequality being tied to social constructions of masculinity and male

\footnotetext{
${ }^{31}$ Lang J "Evolving the gender agenda: Men, gender and development organisations". Paper presented to The Role of Men and Boys in Achieving Gender Equality, Expert Group Meeting, organised by DAW in collaboration with ILO and UNAIDS, 21-24 October 2003, Brasilia, Brazil, http://www.un.org/womenwatch/daw/egm/men-boys2003/index.html (accessed 24 January 2011) 8-9.

32 Chant S \& Guttman M Mainstreaming men into gender and development Oxfam GB (2000) 6; Charlesworth (fn 9 above) 3 .

${ }^{33}$ Chant \& Guttman, ibid.
} 
identity. In addition, men's own health and wellbeing are limited by contemporary constructions of manhood. ${ }^{34}$

Regrettably, after more than three decades of the ascension of the rhetoric of gender mainstreaming, agendas of gender equality are widely seen as the concerns of women and not men. Understandably, it was women who squarely placed gender issues on the global political agenda. The logic goes that since it is women who are disadvantaged by gender inequality, it is women who have a claim for redress, and thus gender issues are of no concern to men. However, this logic is no longer sustainable for, as Connell observes, "men and boys are unavoidably involved in gender issues". ${ }^{35}$ After all, men or, more accurately, specific groups of men, control the resources required to execute women's claims for fairness. However, more broadly, gender inequalities are based in gender relations, in the complex webs of relationships that exist at every level of human experience. ${ }^{36}$

Ugo's description is apposite in describing the African scenario on gender equality:

"In the African traditional context, children belonged to the whole society. Elder age groups were expected to admonish their younger counterparts. All adults had a right and mandate to discipline all children. The burden of taking care of children was on the shoulders of the society and not a given gender. Responsibilities were equitably distributed in African traditional societies...Women were victims of injustice in traditional African culture not because of what the society did to them but because of what the society did not do to them. Boys grew up knowing that they had to be strong, hardworking and wise so that they could take good care of their wives, children and society. Girls grew up knowing that they had to be hardworking and submissive so that they could find good husbands who would take good care of them. In other words, it wasn't up to them to make their lives successful. It was up to their future husbands. This notion robbed them of the initiative and creativity to make a choice which would make a difference." 37

Including men in gender and development work in Africa is therefore necessary and inevitable because gender inequality is intimately tied to men's practices and identities, men's participation in complex and diverse gender relations, and masculine discourses and culture. Fostering gender equality requires change in these same arenas of men's lives and relations. At the same time, involving men in efforts towards gender equality runs the risk of reinforcing men's existing power

\footnotetext{
${ }^{34}$ Kaufman M "The AIM framework: addressing and involving men and boys to promote gender equality and end gender discrimination and violence", UNICEF, 31 March 2003, http://www.michaelkaufman.com/articles/pdf/the-aim-framework.pdf (accessed 24 January 2011); Wendoh S \& Wallace T "Re-Thinking gender mainstreaming in African NGOs and communities" (2005) 13(2) Gender \& Development 70.

${ }^{35}$ Connell RW "The role of men and boys in achieving gender equality" Expert Group Meeting, organised by DAW in collaboration with ILO and UNAIDS, 21-24 October 2003, Brasilia, Brazil, http://www.un.org/womenwatch/daw/egm/men-boys2003/index.html (accessed 24 January 2011) 3.

${ }^{36}$ Connell, ibid; Esplen, (fn 27 above) ibid.

${ }^{37}$ Ugo D "Gender inequality in Africa" AfricanLoft, 9 June 2007, at http://www.africanloft.com/genderinequality-in-africa/ (accessed 24 January 2011).
} 
and jeopardising resources and funding directed at women. ${ }^{38}$ The goal of promoting gender justice must therefore remain central.

In patriarchal societies such as those dominant in Africa, rather than seeing men only as obstacles to women's empowerment, it is worth recognising that some men already are playing a role in fostering gender equality. Some men are already living in gender-fair ways: men who respect and care for the women and girls in their lives, rejecting customary, sexist norms of manhood. Individual men in trade unions and governments have been important advocates for women's rights. Small numbers of men are engaged in public efforts in support of gender equality in fields such as violence against women, HIV/AIDS and schooling. ${ }^{39}$ While empirical data are not readily available, it is safe to observe that many African men show both resistance to, and support for, gender equality. Including men in gender and development work involves the recognition of this diversity and the adoption of different strategies in responding to resistance while mobilising and building on the available support.

There are other reasons why efforts at gender reform should address men to deal with both the detrimental effects of male exclusion and the positive effects of male inclusion. First, the longstanding equation of "gender" with women potentially marginalises women and women's struggles. ${ }^{40}$ Leaving men out of efforts towards gender equality can provoke male hostility and retaliation, arising out of both exclusion and more general anxieties among men, as some development projects have found. ${ }^{41}$ Focusing only on women, in relation to such issues as economic participation, credit or sexual and reproductive health, for example, can leave women with yet more work to do and thus intensify gender inequalities. Womenonly projects can mean that women still have to deal with unsympathetic men and patriarchal power relations, and can leave women with sole responsibility for sexual health, family nutrition, and so on. ${ }^{42}$

In transforming the sphere of multilateral trading systems in Africa, both the United Nations Conference on Trade and Development (UNCTAD) and the United Nations Development Programme (UNDP) have canvassed and adopted this suggested praxis in the consciousness that effective gender mainstreaming includes not only legislative reform on issues such as access to land and policies to facilitate women's access to other resources and to capacity-building, but also incentives and even subsidies for women's businesses so that they can develop export crops and compete in the commercialisation of, for example, wood and fisheries. ${ }^{43}$

\footnotetext{
${ }^{38}$ Kaufman (fn 34 above).

${ }^{39}$ See generally Kim JC \& CH Watts "Gaining a foothold: tackling poverty, gender inequality, and HIV in Africa” (2005) 331(7519) British Medical Journal 769.

${ }^{40}$ Kaufman (fn 34 above) 3.

${ }^{41}$ Chant \& Guttman (fn 32 above) 25; Lang (fn 31 above) 9.

${ }^{42}$ See Chant \& Guttman, ibid.

${ }^{43}$ See UNCTAD \& UNDP Mainstreaming gender into trade and development strategies in Africa (2008) 16.
} 
As another tangential pointer, the Power of Reconciliation Project initiated by the Satyana Initiative in South Africa in 2006, demonstrates the invaluable role that an inclusionary agenda to gender reconciliation may play in the broader frame of gender mainstreaming. The Power of Reconciliation Project created a rare forum for women and men to jointly confront gender injustice and unravel the insidious knots of cultural conditioning and oppression relating to gender and sexuality. In this unique context, obscure issues of gender are confronted unflinchingly as participants plumb the depths of their experiences and move beyond habitual ways of relating to discover new forms of healing and authentic intimacy between the sexes. ${ }^{44}$

Including men in grassroots work on gender and development in Africa has important benefits. Given that many African women already interact with men on a daily basis in their households and public lives, involving men can make interventions more relevant and workable. ${ }^{45}$ Male inclusion invariably increases men's responsibility for change. Explicitly addressing men can increase men's belief that they too will gain from gender equality and can engage men directly in the renegotiation of gender relations. Male inclusion can speak to many men's sense of anxiety and fear as "traditional" masculinities are undermined. Men's suffering (such as men's growing burden of illness or social and economic marginalisation among young, poor men) is worth addressing in its own right as well as in terms of its potential impact on women. ${ }^{46}$

Many African men receive formal and informal benefits from gender inequalities, including material rewards and interpersonal power. At the same time, men also pay significant costs, particularly in terms of their emotional and physical health. More widely, men can be and are motivated by interests other than those associated with gender privilege. ${ }^{47}$ There are important resources in men's lives for the construction of gender-equitable masculinities and forms of selfhood, such as men's concerns for children, intimacies with women, and ethical and political commitments. Thus, while men ought to change, it is also in men's interest to change. There is a moral imperative that men give up their unjust share of power, and men themselves will benefit from advancing towards gender equality in African communities.

None of this means that women's groups and gender-related programming must include men. There continue to be reasons why "feminine space", involving exclusively women and women-specific programmes, are vital: to support those who are most disadvantaged by pervasive gender inequalities; to maintain women's solidarity and leadership; and to foster women's consciousness-raising and collective empowerment. Nor should growing attention to male involvement

\footnotetext{
${ }^{44}$ The Satyana Institute had chosen South Africa, alongside Australia, Canada, Croatia, India and the United States, as pilot countries for a looming global project. See Keepin W \& Brix C "Divine duality: reconciliation between women and men" (2008) 4(2) Kosmos 1.

${ }^{45}$ UNCTAD \& UNDP, (fn 43 above) 18.

${ }^{46}$ Chant \& Guttman (fn 32 above) ibid.

${ }^{47}$ See generally Esplen (fn 27 above) 11.
} 
threaten resources for women and women's programmes. At the same time, reaching men to reduce gender inequalities against women is by definition spending money to meet the interests and needs of women, and will expand the financial and political support available to women's programmes. ${ }^{48}$

\section{GENDER MAINSTREAMING IN AFRICA: TOWARDS AN INCLUSIVE AGENDA}

Despite a plethora of policy statements and pronouncements, there is little evidence that a concern with women, let alone with gender, has been integrated into programmes and planning among development agencies, bureaucracies, funding agencies or governments. ${ }^{49}$ Despite three decades of effort, actual development work has continued to marginalise women and women's concerns. Furthermore, the shift from WID to GAD did little to shake the lack of attention to male gender identities, and there is little evidence of "male-inclusive" gender initiatives. ${ }^{50}$

There are both good and bad reasons for the ongoing absence of men-as-men in GAD policy and programming. Given the persistence of widespread gender inequalities which disadvantage women and the limited availability of resources for GAD work, there are good reasons for continuing to focus on women. ${ }^{51}$ There are understandable fears as to what may happen if men are invited in, in the context of a history of grassroots examples where women have lost out, men have taken over, and women-oriented projects have been diluted or subverted. ${ }^{52}$ Women may be hesitant to share a realm which has historically been a place of sanctuary for them. ${ }^{53}$ In addition, in development organisations there is some resistance to a GAD approach because, for example, it is harder to address gender relations; interventions in social relations of gender may be seen as inappropriate "cultural interference"; and GAD calls for more fundamental transformations which may be seen as "confrontational". 54

Patriarchal organisational structures and cultures of development organisations, and of governments, inhibit attention to men's roles in gender equality in Africa. ${ }^{55}$ Women's sectors in development often are weak, marginalised and under-funded, and have had little impact on mainstream developmental policies, programmes and processes. ${ }^{56}$ In this context, Chant and Guttman contend that "[m]en may feel threatened by women's challenge to male entitlements, they may feel that gender has nothing to do with them, they are less likely to recognise gender relations as

\footnotetext{
${ }^{48}$ Kaufman (fn 34 above); Flood 2004 (fn 5 above).

${ }^{49}$ See Chant \& Guttman (fn 32 above).

${ }^{50}$ Chant \& Guttman (fn 32 above) 2, 14.

51 Ibid.

${ }^{52}$ Ibid.

${ }^{53}$ Lang (fn 31 above).

${ }^{54}$ Chant \& Guttman (fn 32 above) 20.

55 See Palmary \& Nunez (fn 28 above).

${ }^{56}$ Chant \& Guttman (fn 32 above).
} 
unequal, or may avoid raising gender issues for fear of disapproval and ridicule". ${ }^{57}$ Extending this view to the African context, men may also feel that, as men, they have been stereotyped as being identical in all respects and may resent approaches that are tactless or overly negative. Overall, there should be more enthusiasm to include African men in GAD if women had been given an equal place and voice in development in general and if worldwide gender inequalities had lessened. Nevertheless, including men will be critical to the successful creation of gender equality.

The argument for the inclusion of men in gender mainstreaming and their integration into development programming and policies even finds further reinforcement in the peculiarities of the African milieu, having regard to the phenomena of HIV/AIDS, armed conflicts, internally displaced persons and weakened governance, among others. In a continent reputed to be the epicentre of civil wars, armed conflict, strife and political upheaval, it has become imperative for developmental policy-makers to understand the relationship between gender roles and conflict. Such an understanding is essential to assessing the prospects for peace and also offers insight into post-conflict dynamics of power, control and competition.

The intersectionality of gender relations and conflicts in Africa cannot be ignored since this is where the challenges to, or opportunities of, successful development programming often take root. It is no longer difficult, therefore, to find reasons why African men are seemingly reacting to the mainstreaming paradigm in a positive rather than negative way. Beyond the traditional roles of women as mere passive victims of armed conflict, African women are assuming new roles in Africa's conflict situations as fighters, community leaders, social organisers, workers, farmers, traders and welfare workers, amongst others, and their bravery in seeking to end armed conflicts is gaining global attention. ${ }^{58}$ In recent times African men, particularly demobilised soldiers, former rebels, previously conscripted boy soldiers and men in government, have begun to view women as constituting a category of persons with common characteristics that lend themselves to being employed in the twin projects of post-conflict reconstruction and peace-building. ${ }^{59}$ There can hardly be any more auspicious premise, beneficial to men and boys, for a gendered approach to development in the frail states of Africa.

\footnotetext{
${ }^{57}$ See Chant \& Guttman (fn 32 above) 21-22.

${ }^{58}$ Pankhurst D "The 'sex war' and other wars: Towards a feminist approach to peace building (2003) 13 (2\&3) Development in Practice 154, 157; Katame, K (ed) Gender and Peace building in Africa Oslo: NUPI (2004) 5-8; United States Agency for Development (USAID) Best Practices: Gender and conflict in Africa USAID (2005) 2.

${ }^{59}$ See USAID, ibid, 6; Iheduru OM Contending issues in African development: advances, challenges, and the future Westport, CT: Greenwood Press (2001) 12; Pankhurst, above, at 162-164; Obiekwe K "In search of appropriate peacemaking/peace building paradigm in dealing with Africa's intrastate violent conflicts: Considering Lederach's faith-based conflict transformation and peacebuilding approach" (2009) 13 Journal of Peace, Conflict and Development, at http://www.peacestudiesjournal.org.uk/d1/Issue\%2013\% 20article\%2011\%20formatted\%20pdf.pdf (accessed 16 March 2011).
} 
Which modalities, then, would guide men's involvement in gender and developmental work in Africa? First and foremost, conscious strategies are needed to deal with resistance. Other stakeholders, including donors, are not always sympathetic to gender mainstreaming and may be resistant in active or passive ways. One strategy to address this is to promote and disseminate the use of sex disaggregated data and gender analysis in relation to the policy and programme areas in question; for example, in relation to rural development and economic growth. The bottom line is that any incorporation of men and men's gendered issues into development practice and policy should further the feminist goal of gender equality. As in gender policy in general, there is the danger that in speaking to men's concerns, interests and problems, the impetus for justice for women will be weakened or slide into an anti-feminist backlash. ${ }^{60}$ Yet gender equality initiatives must include an engagement with men and masculinities if they are to be effective. Thus the rationale of gender equality must be kept central, such that the "involvement of men-as-men in GAD [will be] couched within a clear feminist political agenda". 61

In taking on such work, development practitioners can learn from the positive experiences of male involvement in GAD documented for example by Wendoh \& Wallace and the pioneering work of Transform Africa. ${ }^{62}$ Practitioners and policymakers can make use of a rapidly growing literature offering frameworks with which to articulate the role of men and boys in achieving gender equality. Three recent documents which do this are Mayoux \& Mackie's Guide, prepared in accordance with the ILO's Strategy on Women's Entrepreneurship Development and endorsed by the ILO Governing Body in March 2008. The Guide contributes to the development of tools and support services for women entrepreneurs and to mainstreaming gender in micro and small enterprise development methodologies. Others are the AU Commission's The Road to Gender Equality in Africa, 2004 as well as the Expert Group Report, 2003. Other important discussions of men's roles in progress towards gender equality in Africa are given by Palmary \& Nunez. Also in pro-feminist academic writing on men and masculinities there is a growing articulation of men's relation to feminism, exploring questions of epistemology and political practice, including recent pro-feminist activism and writing on the Internet by men; for example, the resources collected at Siyanda: Mainstreaming Gender Equality. ${ }^{63}$

Beyond the overarching principle of gender equality there are further aspects to any effective and beneficial strategy of male inclusion. One is that funding for work with men and boys should not be at the expense of funding for gender equality work

\footnotetext{
${ }^{60}$ Connell 2003 (fn 35 above) ibid.

${ }^{61}$ Chant \& Guttman (fn 32 above) 43.

${ }^{62}$ The materials referred to in this paragraph have been cited at various points in this article or are contained in the Bibliography below.

${ }^{63}$ See "Siyanda: Mainstreaming Gender Equality" at http://www.siyanda.org/ (accessed 27 March 2011).
} 
with women and girls. ${ }^{64}$ Another is that development work with men should be done in partnership with women. Partnerships with women and women's groups enable men to learn from existing efforts and scholarship rather than reinventing the wheel. ${ }^{65}$ They lessen the risk that men will collude in or turn out to be complicit with dominant and oppressive forms of masculinity. Such partnerships are also a powerful and practical demonstration of men and women's shared interest in democratic and peaceful gender relations. Another element is that, rather than having separate and parallel policies for women and men, we should adopt integrated gender policies which address the relations between women and men. ${ }^{66}$

Lang argues that the promotion of greater gender self-awareness can produce shifts in organisational culture and gender relations and encourage deeper partnerships among and between different groups of men and women. Development agencies themselves should therefore model gender equality, addressing their own policies, staff and organisational culture. ${ }^{67}$ This should include reflection by male staff on their own experience, privilege and gendered practice.

A comprehensive illustration of such practice comes from the UN Working Group on Men and Gender Equality. Created in the late 1990s, this group involved both male and female staff from UN-based organisations. The group invited men to reflect on the connections between gender equality and their personal and professional lives, using this as the springboard for broader organisational change. ${ }^{68}$ Another example is Oxfam's Gender Equality and Men (GEM) project which began in 2002 to assist Oxfam in exploring ways to advance gender equality and poverty reduction by incorporating men and boys more fully into its work on gender. The project included an internal advocacy component, designed to encourage men inside the organisation to think about their personal commitment to gender equality and what that meant for their day-to-day work. ${ }^{69}$

In sum, the case made in this article is to the following effect: gender mainstreaming projects in Africa must ensure that data is disaggregated by sex, geographic origin, age or ethnicity in order to expose objective rather than stereotyped disparities. Gender mainstreaming policies which seek to provide equal opportunities for both men and women must address social, cultural and economic factors that have historically denied women equal access to resources. For example, programmes that provide access to loan and credit for women in certain rural communities must address community practices which seclude and exclude women from public life. Similarly, macro-economic policies which reinforce the gendered notions of family and undermine a shared role in parenting must be reviewed. Analysis should include the causes of problems facing women and children and an

\footnotetext{
${ }^{64}$ See Expert Group "The role of men and boys in achieving gender equality: Report of the Expert Group Meeting" organised by DAW in collaboration with ILO and UNAIDS, 21-24 October 2003, Brasilia, Brazil, http://www.un.org/womenwatch/daw/egm/men-boys2003/index.html (accessed 24 January 2011). .

${ }^{65}$ Mayoux \& Mackie (fn 29 above).

${ }^{66}$ Expert Group (fn 64 above); Mayoux \& Mackie (fn 29 above) ibid.

${ }^{67}$ Lang (fn 31 above).

${ }^{68}$ Flood (fn 5 above).

${ }^{69}$ Esplen (fn 27 above).
} 
understanding of the linkages between problems. In this context, analysts should examine whether the allocation of national resources actually reinforce discrimination against women or girls. Preferential access of girls to education should then be made available in places where women (and girls) have historically been disadvantaged.

African women's voices must also begin to make landmark contributions to constitutional and legal development. Women's groups in Brazil, India, Kenya, and South Africa have made use of the constitutional reform process to give priority to international human rights conventions advancing the rights and dignity of women. This trend should be emulated more rigorously across the length and breadth of Africa.

\section{CONCLUSION}

This article has shown that, since 1995, steps to integrate a gender perspective within the UN human rights and development framework have been taken in various fora. The UN General Assembly and the Economic and Social Council have given detailed guidance with regard to the principles and practical implications of this approach. These provided a definition of the concept of gender mainstreaming, a set of principles and specific recommendations for action by inter-governmental machinery and at the institutional level. The agreed conclusions also make repeated reference to the need to mainstream a gender perspective systematically in all areas, including human rights. Mainstreaming human rights into developmental work ensures that data is disaggregated by sex and that women and children are visible in budgets to the maximum extent made possible by available resources, as required by several human rights standards.

Notwithstanding the urgency in the global agenda to elevate and empower women in the equation of development, a new trend of thought now conceives of an inclusionary approach in which men would play a role in transformative development.

This article has indicated that the impetus for men's involvement in genderrelated development work in Africa is likely to increase in the next few years. It is fuelled by ongoing shifts in gender relations, feminist and pro-feminist recognition of the need to transform and reconstruct masculinities, and trends in particular fields such as development work, as well as more troubling agendas such as nonand anti-feminist interest in "correcting the balance" by focusing on men. There is no doubt that involving men in efforts towards gender equality has the potential to greatly enhance the impact and reach of this work in African states. However, whether or not it does so will depend on the play of political and cultural forces and relations. Still, building a world of gender justice will bring benefit to both women and men, and the reconstruction of gender will require our shared commitment and involvement. 
Far from being an ex cathedra pronouncement on all the dynamics that would inform an integrative, inclusionary approach towards transformative development in Africa, this article will have served its purpose if it stimulates further intellectual enquiry.

\section{BIBLIOGRAPHY}

African Union (AU) Decision on the African Women's Decade, Assembly/AU/Dec.229 (XII), Addis Ababa, Ethiopia, 1-3 February 2009.

Andrews P "Democracy stops at my front door: obstacles to gender equality in South Africa” (2007) 5 Loyola International Law Review 15-28.

Baliamoune-Lutz M \& McGillivray M "Gender inequality and growth: evidence from Sub-Saharan Africa and Arab Countries" 1 September 2007, available at http://www.uneca.org/aec/documents/Mina\%20Baliamoune-Lutz.pdf (accessed 24 January 2011).

Baliamoune-Lutz M "Globalisation and gender inequality: is Africa different?" (2007) 16(2) Journal of African Economies 301-348.

Budig MJ "Gender, self-employment, and earnings: the interlocking structures of family and professional status" (2006) 20 Gender Society 725-753.

Chant S \& Guttman M Mainstreaming men into gender and development Oxford: Oxfam GB (2000).

Charlesworth $\mathrm{H}$ "Not waving but drowning: gender mainstreaming and human rights in the United Nations" (2005) 18 Harvard Human Rights Journal 1-18.

Connell RW Masculinities Allen \& Unwin (1995).

Connell RW "The role of men and boys in achieving gender equality" Expert Group Meeting, organised by DAW in collaboration with ILO and UNAIDS, 21-24 October 2003, Brasilia, Brazil, http://www.un.org/womenwatch/daw/egm/menboys2003/index.html (accessed 24 January 2011).

Datta K "A coming of age? Re-conceptualising gender and development in urban Botswana” (2004) 30(2) Journal of Southern African Studies 251-268.

Derbyshire, H Gender manual: A practical guide for development policy makers and practitioners DFID (2002).

De Waal M "Evaluating gender mainstreaming in development projects" (2006) 16(2) Development in Practice 209-214. 
Egunyomi D "Access to basic education for girls: the Nigerian experience", in A Oduaran \& HS Bhola (eds) Widening Access to Education as Social Justice Dordrecht: Springer (2006) 427-440.

Esplen E Engaging men in gender equality: positive strategies and approaches Sussex: Institute of Development Studies (2006).

Expert Group "The role of men and boys in achieving gender equality: Report of the Expert Group Meeting" organised by DAW in collaboration with ILO and UNAIDS, 21-24 October 2003, Brasilia, Brazil, http://www.un.org/ womenwatch/daw/egm/men-boys2003/index.html (accessed 24 January 2011).

Flood M "Fatherhood and fatherlessness" The Australia Institute, Discussion Paper No 59, November 2003, Sydney.

Flood M “Men, gender and development” (2004) 64 Development Bulletin 26-30.

Franck AK \& Spehar A Women's labour migration in the context of globalisation WIDE (2010).

Gardner T \& McKinney M “The commodification of women's work: theorizing the advancement of African women" (2007) 13 Buffalo Human Rights Law Review 33-72.

Gardiner JK (ed) Masculinity Studies and Feminist Theory: New Directions New York: Columbia University Press (2002).

Gawanas B "The African Union: concepts and implementation mechanisms relating to human rights" in A Bösl \& J Diescho (eds) Human Rights in Africa: Legal Perspectives on their Protection and Promotion Konrad-Adenauer-Stiftung (2009) 132-162.

Hannan C "Gender mainstreaming: Some experience from the United Nations" Paper presented at a conference on Gender Mainstreaming - A way towards equality, Berne, 20 June 2003.

Iheduru OM Contending issues in African development: advances, challenges, and the future Greenwood Press (2001).

Jahan $\mathrm{R}$ The elusive agenda: Mainstreaming women in development Zed Books (1995).

Katame K (ed) Gender and peace building in Africa NUPI (2004).

Kaufman M "The AIM framework: addressing and involving men and boys to promote gender equality and end gender discrimination and violence", UNICEF, 31 March 2003, http://www.michaelkaufman.com/articles/pdf/the-aimframework.pdf. (accessed 24 January 2011).

Keepin W \& Brix C "Divine duality: reconciliation between women and men" (2008) 4(2) Kosmos 1-16. 
Kim JC \& CH Watts "Gaining a foothold: tackling poverty, gender inequality, and HIV in Africa" (2005) 331British Medical Journal 769-772.

Lang J "Evolving the gender agenda: Men, gender and development organisations" Expert Group Meeting, organised by DAW in collaboration with ILO and UNAIDS, 21-24 October 2003, Brasilia, Brazil, http://www.un.org/ womenwatch/daw/egm/men-boys2003/index.html (accessed 24 January 2011).

Manji F, Jama MF \& Musa R (eds) Breathing life into the African Union Protocol on Women's Rights in Africa Fahamu Books (2006).

Mayoux L \& Mackie G Making the strongest links: a practical guide to mainstreaming gender analysis in value chain development ILO Office (2007).

Meer S "Freedom for women: mainstreaming gender in the South African liberation struggle and beyond" (2005) 13(2) Gender \& Development 36-45.

Obiekwe K "In search of appropriate peacemaking/peace building paradigm in dealing with Africa's intrastate violent conflicts: Considering Lederach's faith-based conflict transformation and peacebuilding approach" (2009) 13 Journal of Peace, Conflict and Development, at http://www.peacestudiesjournal.org.uk/dl/ Issue \%2013\%20article\%2011\%20formatted\%20pdf.pdf (accessed 16 March 2011).

Olowu D "A critique of the rhetoric, ambivalence and promise in the 'Protocol to the African Charter on Human and Peoples' Rights on the Rights of Women in Africa" (2006) 8(1) Human Rights Review 78-101.

Palmary I \& Nunez L "The orthodoxy of gender mainstreaming: reflecting on gender mainstreaming as a strategy for accomplishing the Millennium Development Goals" (2009) 11(1) Journal of Health Management 65-78.

Pankhurst D "The 'sex war' and other wars: Towards a feminist approach to peace building" (2003) 13 (2\&3) Development in Practice 154-177.

Porter F \& Sweetman C (eds) Gender mainstreaming: a critical analysis OxfamGB (2005).

Rao A \& D Kelleher "Is there life after gender mainstreaming?" (2005) 13(2) Gender \& Development 57-69.

Rebouche R "Labour, land, and women's rights in Africa: challenges for the new Protocol on the Rights of Women" (2006) 19(10) Harvard Human Rights Journal 235-256.

Segal L "Changing men: masculinities in context" (1993) 22 Theory \& Society 625641.

Subrahmanian $\mathrm{R}$ "Making sense of gender in shifting institutional contexts: some reflections on gender main streaming" (2004) 35(4) IDS Bulletin 89-94. 
Ugo D "Gender inequality in Africa" AfricanLoft, 9 June 2007, at http://www.africanloft.com/gender-inequality-in-africa/ (accessed 24 January 2011).

United Nations "The Nairobi Forward-Looking Strategies for the Advancement of Women" in World Conference to Review and Appraise the Achievements of the United Nations Decade for Women New York: United Nations (1985).

United Nations Conference on Trade and Development (UNCTAD) \& United Nations Development Programme (UNDP) Mainstreaming gender into trade and development strategies in Africa UNCTAD and UNDP (2008).

United Nations Development Programme SADC Regional Human Development Report UNDP (2000).

United Nations Economic and Social Council (ECOSOC) Agreed Conclusions 1997/2 18 July 1997, General Assembly Official Records; Fifty-Second Session, Supplement No. 3, available at http://www.unhcr.org/refworld/docid/4652c9fc2.html (accessed 24 January 2011).

United States Agency for International Development (USAID) Best practices: Gender and conflict in Africa USAID (2005).

Vojdik VK "Conceptualizing intimate violence and gender equality: a comparative approach" (2008) 31 Fordham International Law Journal 487-527.

Walby S "Comparative gender mainstreaming in a global era" (2005) 7(4) International Feminist Journal of Politics: 453-470.

Wandia M. (2009). "Africa: women's rights - looking back or moving forward?" Pambazuka News, 19 November 2009, at http://allafrica.com/stories/ 200911191103.html (accessed 24 January 2011).

Wendoh S \& Wallace T "Re-Thinking gender mainstreaming in African NGOs and communities" (2005) 13(2) Gender \& Development 70-79. 